\title{
Sperm Granuloma
}

National Cancer Institute

\section{Source}

National Cancer Institute. Sperm Granuloma. NCI Thesaurus. Code C80355.

A lump of extravasated sperm in the paratesticular region in men who have undergone vasectomy. 